\title{
EFFECT OF BIOFUEL ON LIGHT-DUTY VEHICLES ENGINE PERFORMANCE AND LUBE OIL DEGRADATION
}

\author{
M ROPANDI*; Z NAHRUL HAYAWIN*; A A ASTIMAR*; A W NOORSHAMSIANA*; \\ R RIDZUAN* and I ZAWAWI*
}

\begin{abstract}
Biofuel is a renewable, biodegradable and non-toxic fuel that is an alternative to fossil fuel. However, the long-term effect of biodiesel on internal combustion engine operation is not extensively studied. Thus, this study examined the effect of B5 biofuel (blend of 5\% refined, bleached and deodourised palm olein oil (RBDPOo) and 95\% automotive diesel oil (ADO) on engine performance and lube oil degradation of lightduty vehicles, i.e. Mercedes Benz (M), Mitsubishi Storm (MS) and Toyota Hilux (TH), up to $80000 \mathrm{~km}$ mileage. ADO was also used for each vehicle brand for comparison. The engine power and torque were examined using chassis dynamometer. Analysis on wear metal content of lube oil was conducted to indicate engine deterioration level. Results showed insignificant deterioration on engine performance of $M$ and $M S$ vehicles using $A D O$ and $B 5$ but $B 5$ vehicles showed lower torque reduction than $A D O$ vehicles. For lube oil analysis, the properties and wear metal contents in $B 5$ vehicles were within acceptable limit as suggested by the International Council on Combustion Engines (CIMAC). Results of this study concluded that the B5 biofuel can be potentially used for selected vehicle brands without engine modifications and normal service intervals can be applied for $B 5$ vehicles.
\end{abstract}

\section{Keywords: biofuel, diesel engine, engine performance, lube oil degradation, palm olein oil.}

Received: 20 November 2020; Accepted: 1 March 2021; Published online: 19 May 2021.

\section{INTRODUCTION}

Driven by the spiraling cost of fossil fuel, energy security and global warming, alternative energy has become a worldwide priority. Some nations have implemented new renewable energy policies, regulatory controls and regulations to replace fossil fuel with renewable fuel (Lapuerta et al., 2011; Mofijur et al., 2015). The increasing demand for energy, particularly diesel fuel in industrial and transportation sectors, plays an important role for the development of a country (Varuvel et al., 2012). However, the combustion of the automotive diesel

\footnotetext{
Malaysian Palm Oil Board,

6 Persiaran Institusi, Bandar Baru Bangi,

43000 Kajang, Selangor, Malaysia.

E-mail: ridz@mpob.gov.my
}

oil (ADO) emits greenhouse gases (Radhakrishnan et al., 2017), which cause global warming. As a consequence, biofuel is increasingly popular as an alternative fuel to reduce fossil fuel dependency as they are renewable, environmental-friendly, biodegradable and capable of mitigating climate change by expressive carbon dioxide $\left(\mathrm{CO}_{2}\right)$ cycle during combustion process (Puppan, 2002). Biofuels are liquid or gaseous fuels that are commercially derived from renewable sources such as vegetable oil and cellulosic biomass (Demirbas, 2007a).

Vegetable oils are a wonderful bio-based resource, can be used as an alternative fuel of conventional compression ignition engines (Demirbas, 2007b; Huang et al., 2012). Among the vegetable oils olive, palm, soyabean, peanut and sunflower oils are mentionable. One challenge that is required to overcome is the higher viscosity 
of the vegetable oils over the petroleum-based diesel. Sometimes transesterification may help to reduce the viscosity of the vegetable oil-based fuels (Shereena and Thangaraj, 2009). Different parameters such as fatty acid content, reaction temperature and methyl esters have direct influence on the performance of the fuel. Study showed on the direct injected vegetable oils and their esters as an efficient fuel for four stroke, single cylinder diesel engine performance and exhaust emissions (Alton et al., 2001). It also revealed that a higher viscosity, thickening in cold condition and drying with time have some negative impact on atomisation, flow and heavy particulate emissions. In a different study, waste cooking oil was used at different percentages $(10 \%, 20 \%$ and $30 \%)$ in volume to produce biodiesel blends using transesterification process (Abed et al., 2018). Results showed a comparatively lower thermal efficiency of the biodiesel blends was noticed over the diesel fuel. In addition, a higher specific fuel consumption and higher exhaust gas temperature were noticed for the case of biodiesel blends. In addition to vegetable oils, biodiesel, dimethyl ether and Fishcher-Tropsch diesel are also considered as a potential replacement of traditional petroleum-based fuels (Kaur et al., 2017).

Palm oil has huge potential for biofuel application. Malaysia is the world's second largest exporter of palm oil products with more than $87 \%$ worldwide export (Masjuki et al., 2013; Parveez et al.,2020). Apart from its environmental benefits and renewability, biofuels from palm oil are economically competitive compared to fossil fuel (Chin et al., 2019). Owing to this, a mandatory biodiesel blend for transportation sector has been implemented in 2011 in Malaysia as carbon reduction commitment for sustainable development (Lim and Lee, 2012). Therefore, since 1 January 2010, every petrol station in Malaysia started selling B5 biodiesel (5\% methyl ester blended with 95\% ADO) according to the Malaysian governmental regulation (Lim and Teong, 2010).

However, there are some issues pertaining to vehicle engines due to the use of this biofuel. The emission and combustion characteristics of the biofuel caused deterioration in the performance of the engines (Ahmad et al., 2011; Behçet, 2011). For improvement, modifications on engines in various aspects are needed when using biofuel (Gumus et al., 2012; Hossain and Davies, 2012). However, previous studies on biofuel focused mainly on laboratory testing of the engine dynamometer and may not reflect the actual vehicle performance (Pelkmans and Debal, 2006; Franco et al., 2013). Hence, the objective of this study was to examine the performance of unmodified engine of light-duty vehicles using B5 biofuel in up to $80000 \mathrm{~km}$ mileage. A blend of $5 \%$ refined, bleached and deodourised palm olein oil (RBDPOo) and 95\% ADO, designated as B5 biofuel, was used for the investigation. In addition, the lubricity performance in terms of used lube oil degradation was also tested and compared with fresh lube oil. Results of this study will be useful in understanding biofuel combustion and emission behaviour as well as providing scientific basis for vehicular emission control.

\section{MATERIALS AND METHOD}

\section{Materials}

The RBDPOo and ADO used for biofuel production were purchased from a commercial local supplier. The ADO was used as control for comparison study with B5. Both ADO and B5 biofuel were stored at $0^{\circ} \mathrm{C}$ before use.

\section{Experimental}

RBDPOo and ADO were melted and homogenised at $70^{\circ} \mathrm{C}$ for $30 \mathrm{~min}$ to destroy any crystal. Binary biofuels were prepared using $\mathrm{RBDPO}$ and ADO in volumetric percentage $(\mathrm{v} / \mathrm{v})$ at a mixing ratio of $5 \%$, by adding $50 \mathrm{ml}$ RBDPOo into $950 \mathrm{ml}$ of ADO in sample bottles. The sample bottle was then vigorously shaken for about 10 min and kept idle for about $5 \mathrm{~min}$ prior to density measurement using portable submersible density meter (Brand: Lemis VDM-250). To prepare 13 000 litres biofuel, skid tank was used by pumping RBDPOo and ADO at a mixing ratio of $5 \%$ and thoroughly mixed using a circulation pump until homogenised. The preparation of B5 biofuel was considered to be complete when the densities at the top, middle and bottom of the skid tank were constant and did not vary beyond 0.006 specific gravity, similar to that of $\mathrm{ADO}$ (control).

A total of 12 units light-duty diesel vehicles were used in this study, comprising of four units of Mitsubishi Storm, four units of Toyota Hilux and four units of Mercedes Benz. For each brand, two vehicles were fueled by B5, while the other two were fueled by ADO as control. The vehicles selection was based on engine technology, such as common rail direct injection and distributor pump. Table 1 shows the general specifications for the vehicles. The selected route was a two-way journey from Klang Valley up to southern part of Perak, covering almost $800 \mathrm{~km}$ per day. Selected routes included $70 \%$ highways and $30 \%$ urban and suburban roads to simulate normal driving conditions in Malaysia. Each vehicle was driven simultaneously using the same route but different fuel to minimise variables, particularly traffic conditions which may affect the outcome. Field trials were conducted for a total of $80000 \mathrm{~km}$ mileage to make it parallel with the standard engine warranty offered for new vehicles in Malaysia. 


\begin{tabular}{lccc}
\multicolumn{4}{c}{ TABLE 1. GENERAL SPECIFICATIONS OF DIFFERENT } \\
LIGHT-DUTY VEHICLES
\end{tabular}

Characterisations. Physical and chemical analyses were carried out for RBDPOo, $\mathrm{ADO}$ and B5. The vehicle performance in terms of power and torque for each fuel was conducted on Mustang chassis dynamometer MD 600 as baseline prior to field trials. Chassis dynamometer functions as simulator for a wide range of engine application, similar to the actual behaviour when operated on the road (Amir et al., 2013). Vehicles used for the field trials followed the normal service interval of $5000 \mathrm{~km}$, whereby about $250 \mathrm{ml}$ used lube oil was taken and sent for analysis in accordance to the ASTM D1585 standard method (ASTM, 2015). After achieving cumulative mileage of $80000 \mathrm{~km}$, the performance of the vehicles was re-analysed using chassis dynamometer at 1500$5000 \mathrm{rpm}$ of third and fourth gears. The experiment was conducted in duplicates for each vehicle.

\section{RESULTS AND DISCUSSION}

\section{Physical and Chemical Properties of Fuel}

Fuel properties play important roles in compression ignition engines, engine performance, fuel consumption, vehicle emissions and engine durability. Table 2 shows the chemical and physical properties of RBDPOo, $\mathrm{ADO}$ and $\mathrm{B} 5$ and their comparisons with the Malaysian Diesel Standard (MS123:1993). The properties of fuels provide a basic knowledge of the fuel performance and potential drawback when they are used in diesel engines. The density of RBDPOo, B5 and ADO are $0.9152,0.8595$ and $0.8565 \mathrm{~kg}$ litre $^{-1}$, respectively. The values are close to each other, therefore, the impact of fuel performance and combustion were minimum. B5 showed relatively higher density compared to ADO, which caused the fuel injection system to deliver higher fuel volume, thus, increasing the fuel consumption in B5 light-duty vehicles (Valente et al., 2011). The viscosity of B5 biofuel was $5.066 \mathrm{~mm}^{2} \mathrm{~s}^{-1}$, higher than that of ADO, but it still within the requirement according to the Malaysian Diesel Standard MS123:1993 (1.5-5.8 $\left.\mathrm{mm}^{2} \mathrm{~s}^{-1}\right)$. Fuel viscosity plays an important role on engine performance. Biodiesel is more viscous than fossil diesel as it has large triacylglycerol molecules and higher molecular weight (Williamson and Badr, 1998). Fuel with high viscosity will result in high pumping resistance for fuel deliver, causing the pump to fail prematurely. This also results in poor fuel atomisation by injector leading to poor combustion which will directly affect the engine

TABLE 2. PROPERTIES OF RBDPOo, ADO AND B5 IN COMPARISON WITH THE MALAYSIAN DIESEL STANDARD (MS123:1993)

\begin{tabular}{|c|c|c|c|c|c|c|}
\hline & \multirow{2}{*}{$\begin{array}{c}\text { Test } \\
\text { Method }\end{array}$} & \multirow{2}{*}{ RBDPOo } & \multirow{2}{*}{ ADO } & \multirow{2}{*}{ B5 } & \multicolumn{2}{|c|}{ MS123:1993 } \\
\hline & & & & & Min. & Max. \\
\hline Density at $15^{\circ} \mathrm{C}\left(\mathrm{kg}\right.$ litre $\left.{ }^{-1}\right)$ & D 4052 & 0.9152 & 0.8565 & 0.8595 & - & - \\
\hline Cetane number & D 6890 & 53.6 & 50.6 & 51.5 & 45.0 & - \\
\hline Sulphur content (ppm) & D 4294 & - & 3060 & 2890 & - & 5000 \\
\hline Lubricity $(\mu \mathrm{m})$ & IP450 & 119 & 306 & 234 & - & - \\
\hline Gross calorific value (GCV) $\left(\mathrm{MJ} \mathrm{kg}^{-1}\right)$ & - & 39.740 & 45.258 & 45.165 & - & - \\
\hline Flash point $\left({ }^{\circ} \mathrm{C}\right)$ & - & 284 & 83 & 86 & 60 & - \\
\hline Water content (ppm) & - & 124.5 & 54.1 & 137.1 & - & - \\
\hline Cloud point $\left({ }^{\circ} \mathrm{C}\right)$ & - & 13 & 13 & 13 & - & 18 \\
\hline Pour point $\left({ }^{\circ} \mathrm{C}\right)$ & - & 9 & 3 & 3 & - & 15 \\
\hline Viscosity at $40^{\circ} \mathrm{C}\left(\mathrm{mm}^{2} \mathrm{~s}^{-1}\right)$ & - & 34.8 & 4.5 & 5.1 & 1.5 & 5.8 \\
\hline Cold filter plugging point $\left({ }^{\circ} \mathrm{C}\right)$ & - & - & 9 & 10 & - & - \\
\hline Ash content (mass $\%)$ & - & 0.001 & 0.001 & 0.001 & - & 0.010 \\
\hline Carbon residue on $10 \%$ distillation residue (wt $\%$ ) & - & 4.76 & 0.02 & 0.30 & - & 0.20 \\
\hline
\end{tabular}

Note: RBDPOo - refined, bleached and deodourised palm olein; ADO - automation diesel oil. 
performance and exhaust emission (Valente et al., 2011).

Cetane number is a measure of fuel readiness for autoignition in the combustion chamber after injection (Blin et al., 2013; Jeffrey et al., 2015; Lawlor and Olabi, 2015). Fuel with high cetane number has the benefits of easy cold starting, short ignition delay and low engine noise (Li et al., 2013; Jeffrey et al., 2015). On the contrary, fuel with low cetane number results in combustion deterioration and high emission of hydrocarbons and particulate in the exhaust gas (Jayed et al., 2011). B5 has higher cetane number (51.5) than ADO (50.6), exceeding the minimum value stipulated by the Malaysian Diesel Standard (MS123:1993). In addition, pour point, cloud point and cold filter plugging point (CFPP) are associated with fuel flowability in the fuel system. The cloud point, pour point and CFPP for $\mathrm{B} 5$ were $13^{\circ} \mathrm{C}, 3^{\circ} \mathrm{C}$ and $10^{\circ} \mathrm{C}$, respectively, which were lower than the year-wide ambient temperature in Malaysia $\left(33^{\circ} \mathrm{C}-37^{\circ} \mathrm{C}\right)$. The flash point of fuels determines the flammability of the fuels and is an essential criterion for fuel transportation and storage (Masjuki and Kalam, 2013). The flashpoint of $\mathrm{B} 5$ was $86^{\circ} \mathrm{C}$, which is slightly higher than ADO $\left(83^{\circ} \mathrm{C}\right)$ and complied with the minimum standard requirement (MS123:1993). Hence, B5 is safe where transportation and storage are concerned.

Other important fuel parameters are carbon residue, ash content and gross calorific value (GCV). Carbon residue indicates the tendency of fuel to deposit on the injector and combustion chamber, which invariably affects the engine performance as well as the emission (Jeffrey et al., 2015). The carbon residue (10\% residue) of $\mathrm{B} 5$ was higher than standard (MS 123:1993). However, the ash content of B5 and ADO was similar and thus, it was expected that the wear and tear of the engine moving parts would also be similar. In fuel selection, GCV or energy content is a vital criterion as it reflects combustion efficiency and fuel consumption. This study found that B5 biofuel indicated slightly lower GCV value (45.165 $\mathrm{MJ} \mathrm{kg}^{-1}$ ) than ADO (45.258 MJ kg-1), suggesting higher fuel consumption for B5 compared to ADO in vehicles. It can be inferred that the fuel consumption is high for fuel with high density and low energy content (Mittelbach and Remschmidt, 2007; McCarthy et al., 2011).

\section{Vehicle Power Performance}

The vehicle performance was carried out using a chassis dynamometer at the start $(0 \mathrm{~km})$ and at the end of field trials $(80000 \mathrm{~km})$. Comparisons of maximum power output for both fuels on all vehicles at the start and the end of field trials are shown in Figure 1. However, some of the vehicle performances for certain mileage are not depicted in the figure due to accident, major breakdown and theft. The vehicle major breakdown was not due to fuel-related problems. At the start of field trials, ADO and B5 fueled Toyota Hilux (TH) had an average power output of 69.75 and $59.6 \mathrm{hp}$, respectively. The vehicles fueled by ADO had higher power output which could be attributed to high GCV and lower viscosity, thereby leading to better engine combustion. Owing to lower GCV, the vehicles fueled by B5, namely $\mathrm{TH} 3$ and $\mathrm{TH} 4$, showed slight decrease in their performance, $8.54 \%$ and $7.56 \%$, respectively, at the start and the end of field trials. Saiful Islam et al. (2014) deduced that biodiesel with low energy content caused low engine power output. Other reasons which reduced vehicle power could be wear and tear of vehicle parts and carbon deposited in combustion chamber and injectors.

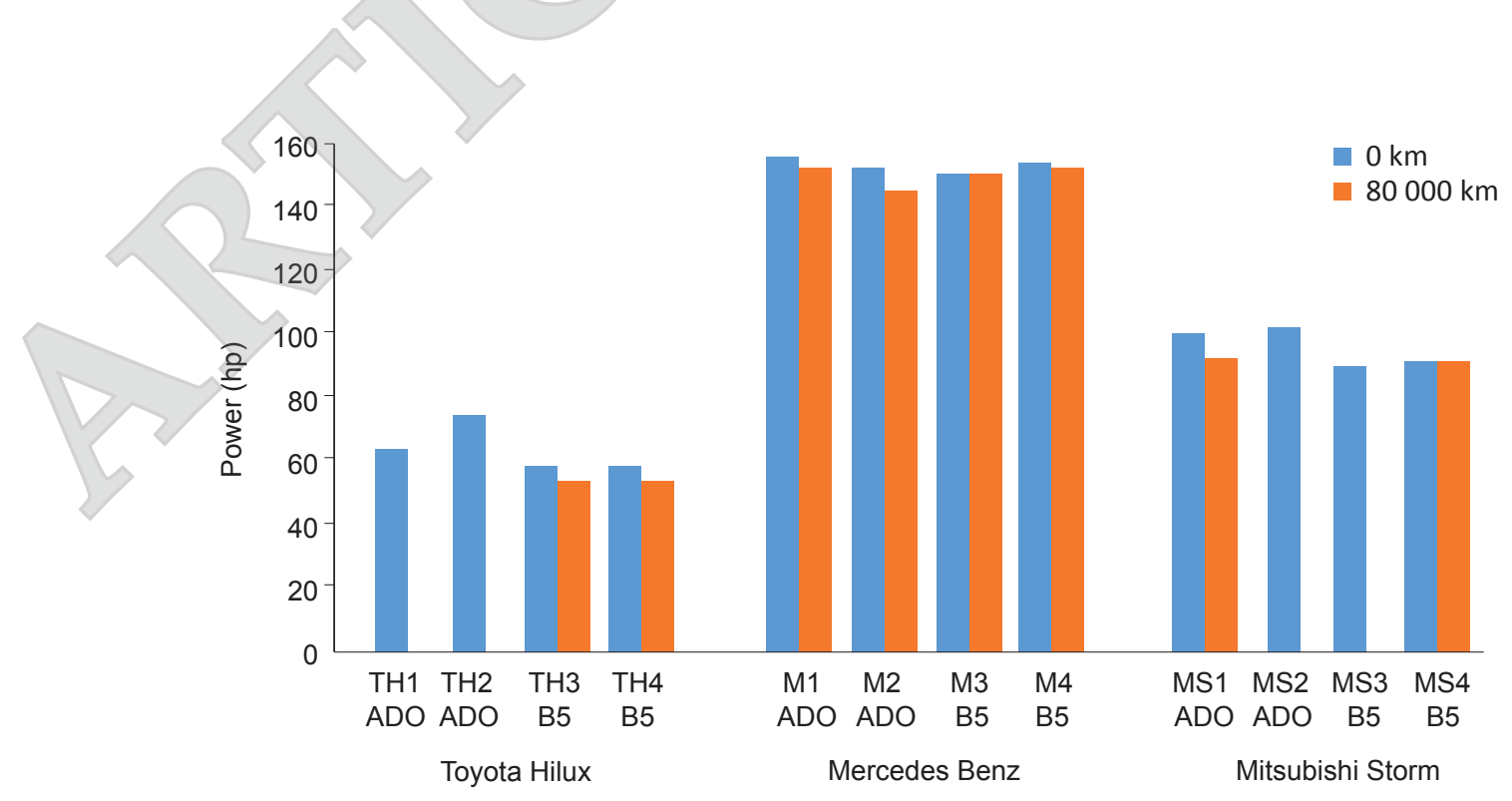

Figure 1. Maximum power output of field trial vehicles measured at $0 \mathrm{~km}$ and $80000 \mathrm{~km}$. 
Birgel et al. (2008) claimed that the overall system performance may be adversely affected due to the formation of deposits within the holes of the injector nozzle or on the exterior injector tip. Similarly, Husnawan et al. (2009) also agreed that the deposits formed in combustion chamber not only affect the engine performance but also its drivability. No comparison can be made on $\mathrm{ADO}$ due to a major breakdown of TH1 at $63000 \mathrm{~km}$, while TH2 was stolen before reaching $80000 \mathrm{~km}$.

Mercedes Benz (M) which employed common rail fuel injection, showed average maximum power outputs of $116.3 \mathrm{~kW}(155.9 \mathrm{hp})$ and $114.7 \mathrm{~kW}(153.8$ $\mathrm{hp}$ ), for ADO and B5, respectively. B5 has lower power output by $1.3 \%$ and this may be related to the GCV of B5 (45.165 MJ kg-1), which was lower by $0.21 \%$ compared to ADO. The reductions of power output at the start and end of the trials for B5 were in the range of $0.19 \%-1.16 \%$, and $1.47 \%-4.97 \%$ for ADO. According to McCarthy et al. (2011), low reduction in power output for B5 is probably due to higher oxygen content in biofuel, thus, improving fuel combustion in the engine. A complete combustion can be achieved by diesel engine fueled by biodiesel due to the presence of oxygen in the biodiesel's molecule.

The distributor pump for diesel injection [Mitsubishi Storm (MS) that used old technology] showed an average maximum power of 103.5 and $91.9 \mathrm{hp}$ for ADO and B5, respectively, at the start of the field trials. Decrease in power output $(11.16 \%)$ on B5 was recorded for vehicles fueled by ADO. After undergoing $80000 \mathrm{~km}$ field trials, the maximum power output of the vehicles fueled by $\mathrm{B} 5$ and ADO decreased by 0.54 and $8.44 \%$, respectively. Lower reduction of power output for B5 was recorded compared to ADO. This could be due to high oxygen content in B5 biofuel, thereby resulting in better combustion, as occurred in $\mathrm{M}$ vehicles (Zulqarnaine et al., 2020; Subhash and Kizhaeral, 2015). Less carbon was deposited in the injectors in the long run, rendering marginal decline in the engine performance. Generally, ADO showed slightly better performance compared to B5 regardless of the engine technologies used. Although common rail diesel injection system is more sensitive and less tolerant to fuel quality, the system employs high injection pressure at low combustion temperature for better engine performance and fuel efficiency while lowering pollutant emission (Jeffrey et al., 2015).

\section{Vehicle Torque Performance}

Figure 2 shows the maximum torque produced from vehicles measured at 0 and $80000 \mathrm{~km}$. Vehicles fueled by B5 showed lower torque compared to vehicles fueled by ADO at $0 \mathrm{~km}$. TH and MS vehicles showed a decrease in performance by $13.6 \%$ and $12.33 \%$ at maximum torque when fueled by B5, while $M$ vehicles showed only a marginal performance decrease of $0.5 \%$ using B5 at $0 \mathrm{~km}$. By comparing the torque at 0 and $80000 \mathrm{~km}$, TH vehicles showed an average reduction of $1.8 \%$ and $3.8 \%$ for vehicles fueled by B5. M vehicles showed a reduction of $1.8 \%$ and $8.51 \%$ for $\mathrm{ADO}$ and torque reductions were $1.7 \%$ and $2.1 \%$ for $\mathrm{B} 5$, which were less than ADO. Meanwhile, for ADO of MS vehicles, lower torque reduction $(1.15 \%)$ was obtained compared to B5 $(4.49 \%)$. The injection characteristics are greatly affected by the viscosities of the fuel (Ilker et al., 2011). The reduced torque performance is also due to the lower heating value of the fuel used. In addition, the torque performance is influenced by energy content (GCV), similar to power. Fuel with lower energy content exhibited lower torque performance as reported by McCarthy et al. (2011).

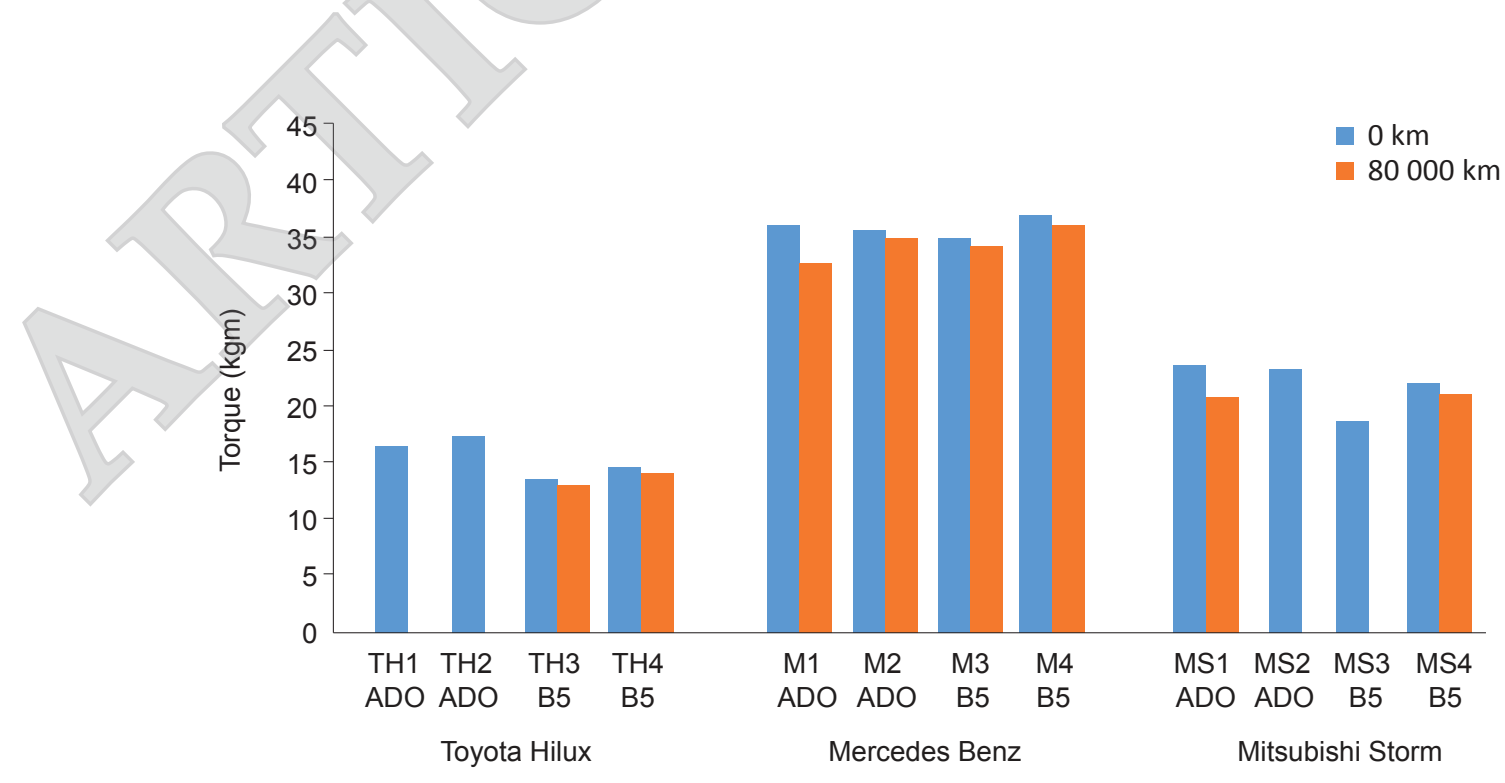

Figure 2. Maximum torque of field trials vehicles measured at start and end of field trials. 


\section{Lube Oil Analysis}

Lubricant oil for engine serves several purposes including friction and wear reduction, protection of engine parts from corrosion and oxidation and transfer of heat from core engine components (Nagy et al., 2019). It has been reported that biodiesel tends to accumulate in engine crankcase affecting lubricant oil quality compared to diesel owing to its higher viscosity (He et al., 2011; Uy et al., 2011). Thus, by analysing the used lube oil of vehicles fueled by B5 and ADO, the engine conditions could be evaluated. In this study, the analysis of used lube oil was carried out during routine services at $5000 \mathrm{~km}$ interval for MS and TH vehicles and $10000 \mathrm{~km}$ interval for M vehicles as recommended by the service center. The effect of fuel used on the performance of lubricant oil in terms of degradation and wear of metal was performed by an accredited external laboratory according to standard method. This can be used to indicate the level of engine deterioration (Vališ et al., 2014). All the analysis of lube oils throughout the routine services up to $80000 \mathrm{~km}$ showed that the properties of used lube oils were still within acceptable limits for all parameters measured. Thus, normal service intervals were appropriate for vehicles fueled by B5. The typical warning limit for metal wear as well as additive deterioration in used lube oil was set by the lube oil laboratory based on their history on engine type, engine technology, type of fuel used, type of lube oil used, service interval, engine operating conditions and top up amount.

In a previous study, the impact of diesel fuel blended with biodiesel from palm oil and jatropha oil were assessed for the evaluation of engine lube oil performance by long duration testing (Gulzar et al., 2016). The blending ratio of biodiesel and diesel fuel was 1:4. A single-cylinder compression ignition (CI) engine was chosen for the testing.
It was noticed that the acidity and viscosity of used blended fuels were increased and decreased, respectively. On the other hand, a slight increase in wear losses and friction were also noticed. In another study, 20\% biodiesel and ultra low sulphur diesel blend were used for the comparative analysis in the assessment of lubricating properties (Xin et al., 2011). Light duty vehicles and 4000 miles of operation were considered for the testing. Analysis showed a little difference in wear scar, viscosity, total base number, total acid number and soot.

Viscosity. Figure 3 shows the viscosity of used lube oils of TH vehicle fueled by B5 and ADO. Typical warning limit for used lube oil viscosity is either $45 \%$ increase or $25 \%$ decrease (viscosity at $40^{\circ} \mathrm{C}$ ) in comparison with fresh lube oil viscosity. Vehicles fueled by ADO were THB0-1 and THB0-2, while THB5-1 and THB5-2 vehicles were fueled by B5. The viscosity of fresh lube oil for THB0-1 was $52.56 \mathrm{~mm}^{2}$ $\mathrm{s}^{-1}$, while the upper and lower limits were 70.96 and $39.43 \mathrm{~mm}^{2} \mathrm{~s}^{-1}$, respectively. The viscosity for THB0-1 showed a decreasing trend due to dilution, which gave rise to lowest viscosity $\left(23.22 \mathrm{~mm}^{2} \mathrm{~s}^{-1}\right)$ at vehicle mileage of $60000 \mathrm{~km}$. After inspection, the vehicles were found to have mechanical problems and unable to continue the trials after $63000 \mathrm{~km}$. For THB0-2, the upper and lower limit viscosities were 170.51 and $94.72 \mathrm{~mm}^{2} \mathrm{~s}^{-1}$. For the first 15000 $\mathrm{km}$, the viscosity of used lube oil was found to be lower $\left(121.8 \mathrm{~mm}^{2} \mathrm{~s}^{-1}\right)$ than fresh lube oil $\left(126.3 \mathrm{~mm}^{2}\right.$ $\mathrm{s}^{-1}$ ). This may be due to contamination that stemmed from fuel dilution which decreased the lubricant viscosity, which in turn, may accelerate wear process as reported by Newell (1999). In addition, Wakiru et al. (2017) postulated that viscosity of fuel and the types of engine could increase or reduce the lubricant viscosity. For automotive application, lubricant viscosity tends to decrease due to dilution when the viscosity of fuel used is lower than that of lubricant.

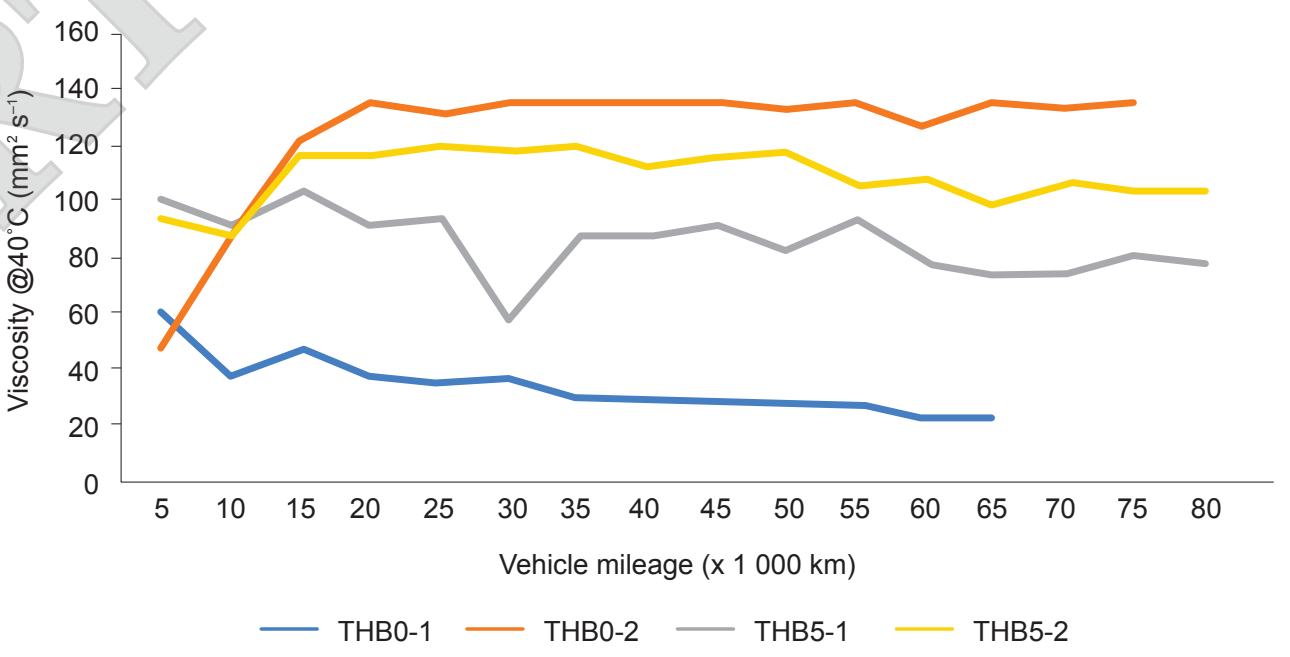

Figure 3. Viscosity of used lube oil at $40^{\circ} \mathrm{C}$ for Toyota Hilux fueled by automation diesel oil (ADO) and B5. 
Subsequently, the viscosity of the used lube oil was almost consistent with an average of $134.06 \mathrm{~mm}^{2} \mathrm{~s}^{-1}$. Used lube oil viscosity of THB5-1 a showed slight decreasing trend with average viscosity of 87.6 $\mathrm{mm}^{2} \mathrm{~s}^{-1}$, which is still within acceptable limits (76.95 $\mathrm{mm}^{2} \mathrm{~s}^{-1}$ to $138.5 \mathrm{~mm}^{2} \mathrm{~s}^{-1}$ ). On the other hand, the upper and lower viscosity limits for THB5-2 were 160.24 and $89.02 \mathrm{~mm}^{2} \mathrm{~s}^{-1}$, respectively. The average viscosity of used lube oil was $112.12 \mathrm{~mm}^{2} \mathrm{~s}^{-1}$ and it is within acceptable limit.

Total base number. Total base number (TBN) in used lube oil is a measurement of reserved alkalinity in lubricating oil to neutralise acidic materials originated from combustion products condensed in engine parts (CIMAC, 2011). The acidic materials are corrosive to the engine components. Typical minimum level for TBN in used lube oil is 2. Based on Figure 4, the TBN for all used lube oils were within limit, indicating that normal service intervals were sufficient to provide required protection to the engine (Marie et al., 2020).

Insoluble pentanes content. Pentanes insoluble is a measure of lube oil degradation due to insoluble contaminants either from fuel combustion and fuel degradation or from oil degradation. Fresh lube oil normally has a value of less than $0.10 \%$ by weight and the warning limit for used lube oil is $1.5 \%$. All the TH vehicles tested fueled by ADO or B5 showed pentanes insoluble to be less than $1.5 \%$. The values for THB0-1 ranged from $0.1 \%-0.24 \%$ and for $\mathrm{THB} 0-2$ the values were in the range of $0.1 \%-0.38 \%$. The values for THB5-1 and THB5-2 were in the range of $0.1 \%$ $0.75 \%$ and $0.1 \%-1.25 \%$, respectively. This indicated that more insoluble contaminants are present in the used lube oil for the vehicles fueled by B5 (Emma, 2010). The amount of insoluble may increase due to fuel contamination, lube oil degradation and incomplete fuel combustion (CIMAC, 2011).
Wear metal. Wear metal analysis is pivotal for maintenance evaluation. Wear metals measured for used lube oil in this study were chromium $(\mathrm{Cr})$, copper $(\mathrm{Cu})$, aluminum $(\mathrm{Al})$, iron $(\mathrm{Fe})$ and lead $(\mathrm{Pb})$. Iron and lead are two main indicators of potential engine failure mostly analysed for used lube oil (Vališ et al., 2014). Figures 5 to 7 show the wear metal contents for aluminum, iron and copper in used lube oils at $80000 \mathrm{~km}$ vehicle service. The wear metals of used lube oils of the tested vehicles were within acceptable limit according to CIMAC (2011). The $\mathrm{Cr}$ and $\mathrm{Pb}$ contents measured in used lube oil throughout the field trials were $1 \mathrm{ppm}$ or less. Their typical warning limits were 40 ppm and 100 ppm, respectively. The origin of $\mathrm{Cr}$ was mainly from wear resistant of alloy steel used to fabricate piston ring, roller bearing and crankshaft. The source of lead could be detected from the crankshaft bearing or from the additive used in the lube oil itself (Yunus et al., 2013). The typical warning limit for $\mathrm{Al}$ content is $40 \mathrm{ppm}$ and the sources of $\mathrm{Al}$ metal were mostly piston, blower and oil pump bushing (Yunus et al., 2013).

All the tested vehicles showed $\mathrm{Al}$ content of 5 ppm and below, except for THB0-2. Slightly high $\mathrm{Al}$ content was obtained for THB0-2 for the first 20 $000 \mathrm{~km}$, which may indicate running condition or mechanical problem. However, after servicing the vehicles at least for four times, the $\mathrm{Al}$ content in the used lube oils was below $5 \mathrm{ppm}$. $\mathrm{Cu}$ is the main component for copper bushing, particularly used for valve train bushing, camshaft bushing, bearing overlay and connecting rod bearing (Yunus et al., 2013). The typical warning limit for $\mathrm{Cu}$ in used lube oil is 40 ppm and all the vehicles tested had Cu content of less than $10 \mathrm{ppm}$ in used lube oils regardless of the type of fuel used. However, THB0-2 showed a slight increase in $\mathrm{Cu}$ content (18 ppm) for $20000 \mathrm{~km}$ service interval. The Fe content in used lube oil mostly originates from piston ring, cylinder liner, valve train

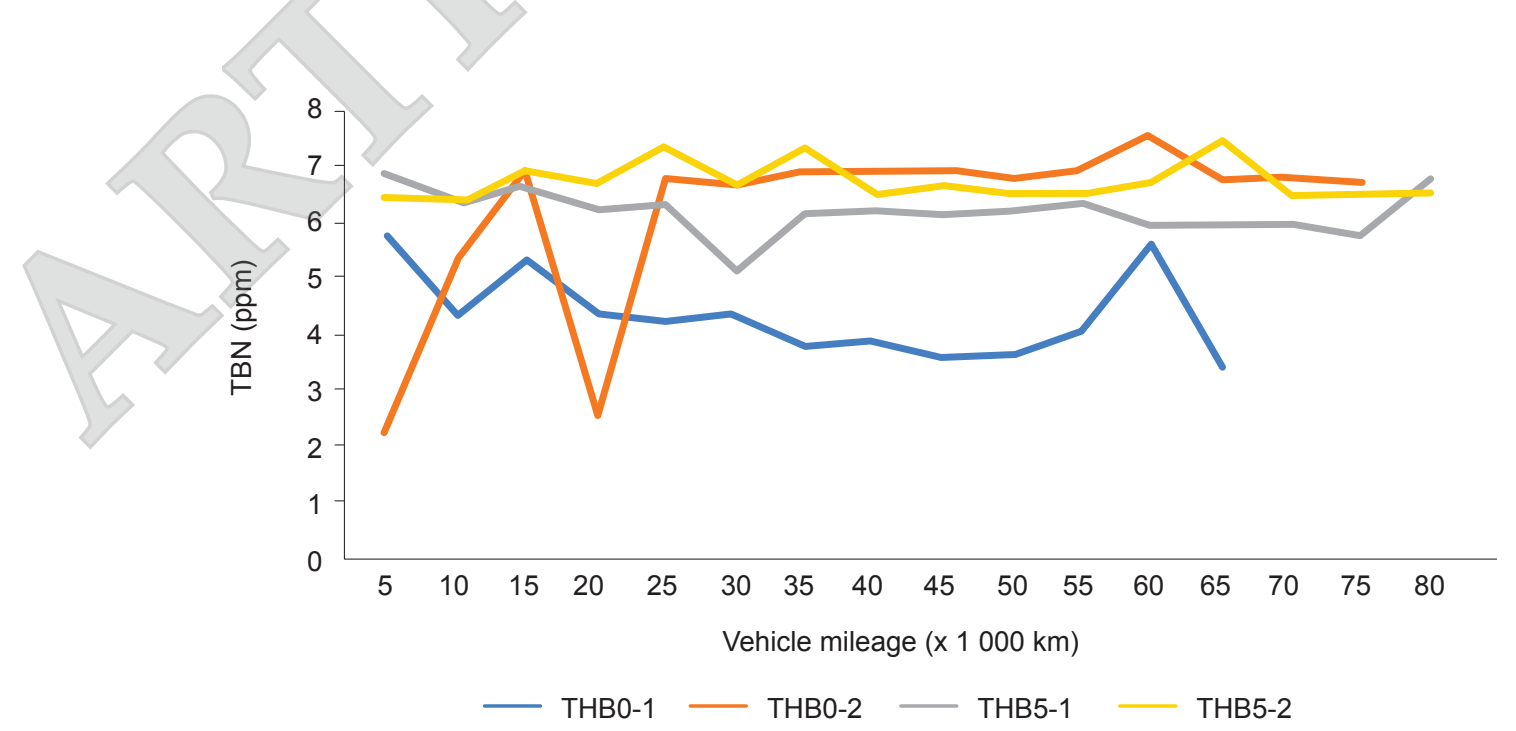

Figure 4. The total base number (TBN) of used lube oil for Toyota Hilux fueled by automation diesel oil (ADO) and B5. 


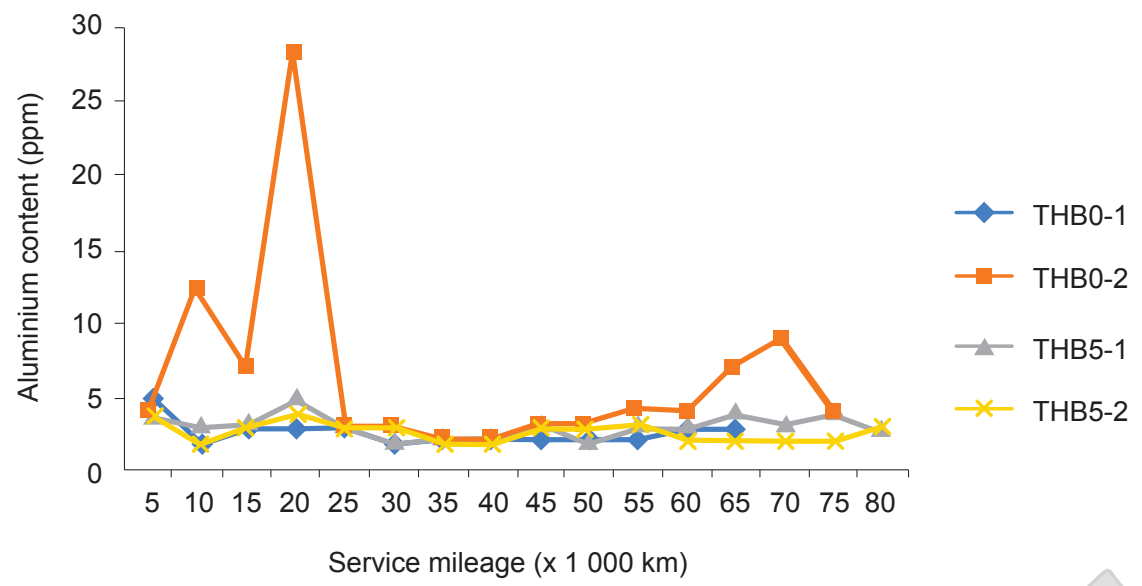

Figure 5. Aluminium (Al) content in used lube oils throughout field trials.

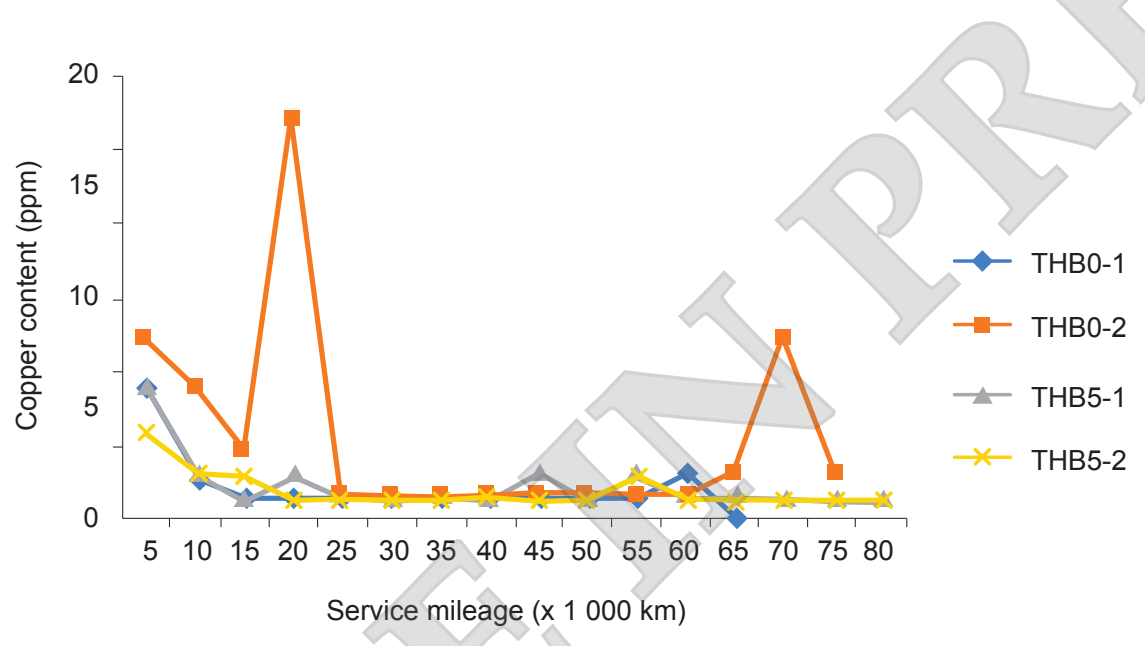

Figure 6. Copper (Cu) content in used lube oils throughout field trials.

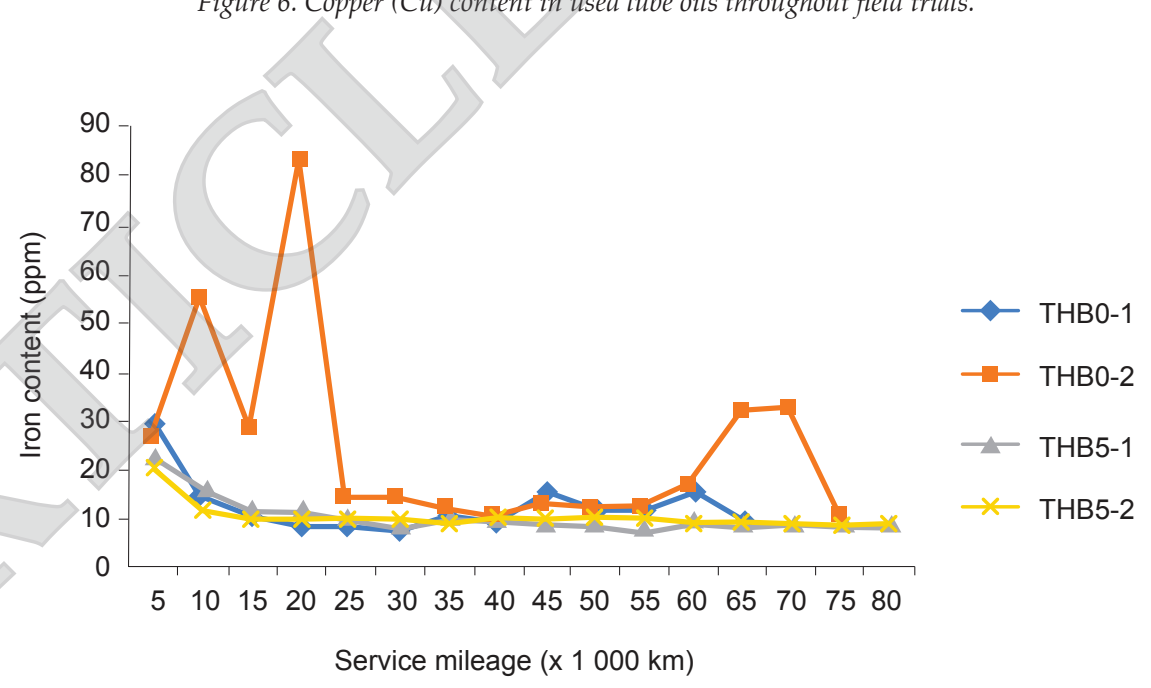

Figure 7. Iron ( $F e$ content in used lube oils throughout field trials.

and camshaft since Fe is the main engine component (Yunus et al., 2013). The typical warning limit for Fe in used lube oil is 100 ppm. Thus, Fe content in lube oil in all the vehicles tested, regardless of fuel and injection technology used, were less than 30 ppm, except for THB0-2, which exhibited slightly higher Fe content of 30 ppm at second, fourth, $13^{\text {th }}$ and $14^{\text {th }}$ lube oil service intervals. However, the reported values were still lower than $100 \mathrm{ppm}$.

Silicon content. Silicon is one of the main micro constituents which may expedite the wear and tear of engine parts as well as contaminate the lube oil (Sendilvelan and Anandanatarajan, 2017). 
Silicon could enter the engine from air filter, engine breathing systems and seal joint materials (Sendilvelan and Anandanatarajan, 2017). Figure 8 shows the silicon content in used lube oils of the vehicles tested. It was found that silicon contents of fresh lube oil for THB0-1, THB0-2 and THB5-1 shared the same results, which were at 22 ppm, while THB5-2 recorded 18 ppm. The limit for silicon (Si) content is 20 ppm.

\section{CONCLUSION}

In this study, blending of 5\% RBDPOo with 95\% ADO was performed to produce B5 biofuel, which demonstrated great potential as alternative renewable fuel for diesel vehicles application. Results from field trials on different types of diesel injection systems showed insignificant deterioration on the engine performance as well as on service intervals. The engine power output of $\mathrm{B} 5$ was lower than $\mathrm{ADO}$ for $\mathrm{TH}$ and $\mathrm{M}$ vehicles but different scenarios were observed for MS vehicles. All the vehicles fueled by B5 showed lower torque reduction for $\mathrm{M}$ and $\mathrm{MS}$ vehicles compared to those fueled by ADO. The analysis of used lube oils showed that all the parameters studied including wear metal content of the engine oil were within acceptable limits. Thus, normal service intervals were appropriate for vehicles fueled by B5 (after $80000 \mathrm{~km}$ mileage). There was no fuel-related problem reported on those vehicles tested. Therefore, it can be inferred that B5 biofuel can be used in diesel vehicles, particularly vehicles and machineries in oil palm plantations as part of strategies to reduce and mitigate the use of fossil fuel consumption and global warming, respectively. Sustainability of palm oil in global market could also be enhanced. Nevertheless, it is suggested that this study be extended for exhaust emission, long term fuel storage stability, maximum blending ratio and shelf life to support the results of the use of biofuel blend in compressed ignition engine, either mobile or stationary.

\section{ACKNOWLEDGEMENT}

The authors would like to thank the Director-General of MPOB for the financial support to conduct this study. The authors also thank all MPOB officers and staff in Engineering and Processing Division as well as Mechanisation and Engineering Unit for providing assistance throughout the field trials.

\section{REFERENCES}

Abed, K A; Morsi, A K; El-Sayed, M M; Shaib, A A and El Gad, M S (2018). Effect of waste cooking-oil biodiesel on performance and exhaust emissions of a diesel engine. Egyptian J. Petroleum, 27: 985-989.

Alton, R; Cetinkaya, S and Yucesu, H S (2001). The potential of using vegetable oil fuels as fuel for diesel engines. Energy Conversion and Management, 42: 529-538.

ASTM (2015). Standard test methods for fatty acids content of pine chemicals, including rosin, tall oil and related products. ASTM D1585-15. ASTM International, West Conshohocken, Pennsylvania, USA.

Ahmad, A; Ghufran, R and Wahid, Z A (2011). Bioenergy from anaerobic degradation of lipids in palm oil mill effluent. Reviews in Environmental Science and Biotechnology, 10(4): 353-376.

Amir, K; Shahrul, A O; Md Norrizam, M J; Norrizal, M; Siti Mariam, B and Manshoor, B (2013). Performance and emissions characteristics of diesel engine fuelled by biodiesel derived from palm oil. Applied Mechanics and Materials, 315: 517-522.

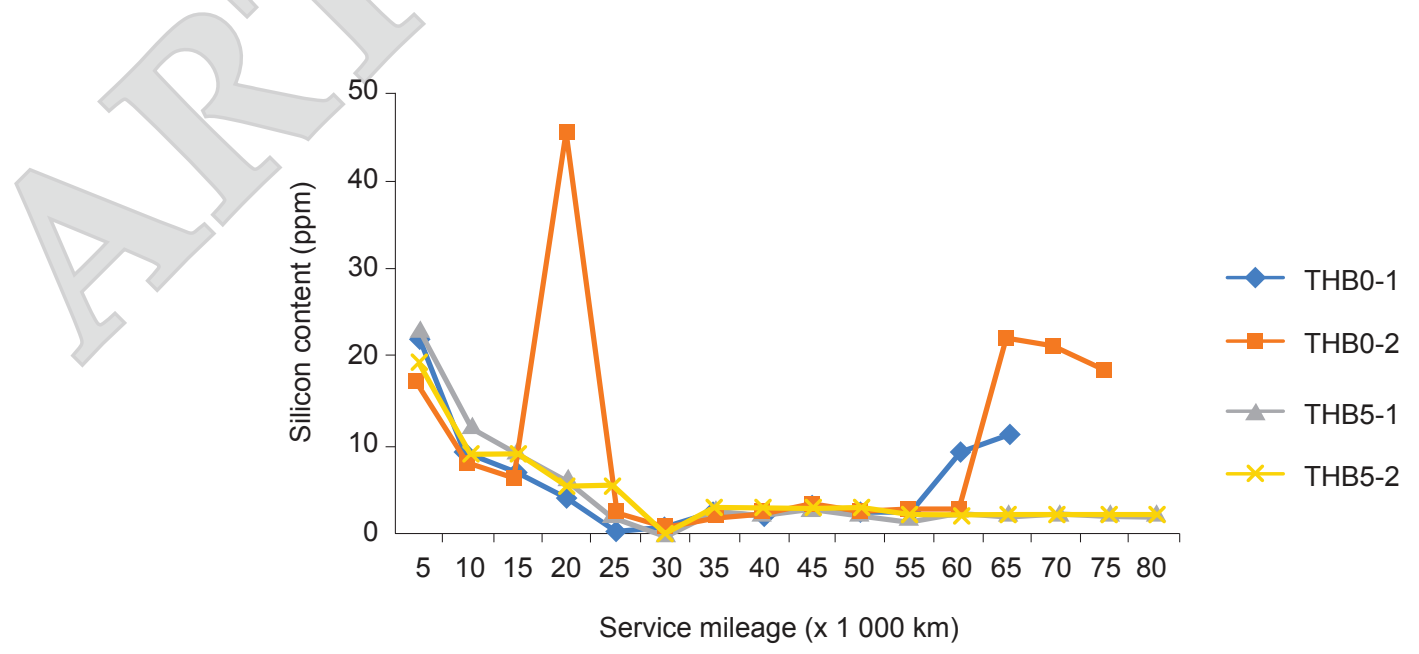

Figure 8. Silicon content in used lube oils throughout field trials. 
Behçet, R (2011). Performance and emission study of waste anchovy fish biodiesel in a diesel engine. Fuel Processing Technology, 92(6): 1187-1194.

Birgel, A; Ladommatos, N; Aleiferis, P and Zülch, $S$ (2008). Deposit formation in the holes of diesel injector nozzles: A critical review. SAE Tech. Paper 2008-01-2383.

Blin, J; Brunschwig, C; Chapuis, A; Changotade, O; Sidibe, S S; Noumi, E S and Girard, P (2013). Characteristics of vegetable oils for use as fuel in stationary diesel engines - Towards specifications for a standard in West Africa. Renewable and Sustainable Energy Reviews, 22: 580-597.

Chin, H; Choong, W; Ra, S; Alwi, W and Hakim, A (2019). A PLS-MGA analysis of farming characteristics on the intentions of smallholder oil palm planters to collect palm residues for biofuel production. Biomass and Bioenergy, 120: 404-416.

CIMAC (2011). Used engine oil analysis User interpretation guide. https://www. cimac.com / cms / upload / Publication_Press / Recommendations/Recommendation_30.pdf, accessed on 1 July 2020.

Demirbas, A (2007a). Progress and recent trends in biofuels. Progress in Energy and Combustion Science, 33: 1-18.

Demirbas, A (2007b). Alternatives to petroleum diesel fuel energy sources. Part B: Economics, Planning and Policy, 2(4): 343-351. DOI: $10.1080 / 15567240600629518$

Emma, M (2010). Monitoring of lubricant degradation with ruler amd mpc. Master thesis, Linkoping University.

Franco, V; Kousoulidou, M; Muntean, M; Ntziachristos, L; Hausberger, S and Dilara, P (2013). Road vehicle emission factors development - A review. Atmospheric Environment, 70: 84-97.

Gumus, M; Sayin, C and Canakci, M (2012). The impact of fuel injection pressure on the exhaust emissions of a direct injection diesel engine fuelled with biodiesel - diesel fuel blends. Fuel, 95: 486-494.

Gulzar, M; Masjuki, H H; Varman, M; Kalam, M A; Zulkifli, N W M; Mufti, R A; Liaquat, A M; Rehan, $\mathrm{Z}$ and Arslan, A (2016). Effects of biodiesel blends on lubricating oil degradation and piston assembly energy losses. Energy, 111: 713-721.

He, X; Williams, A; Christensen, E; Burton, J and McCormick, R (2011). Biodiesel impact on engine lubricant dilution during active regeneration of aftertreatment systems. SAE Int. J. Fuels Lubr. 4: 158178.

Hossain, A K and Davies, P A (2012). Performance, emission and combustion characteristics of an indirect injection (IDI) multi-cylinder compression ignition (CI) engine operating on neat Jatropha and karanj oils preheated by jacket water. Biomass and Bioenergy, 46(Idi): 332-342.

Huang, D; Zhou, H and Lin, L (2012). Biodiesel: an alternative to conventional fuel, international conference on future energy, environment and materials. Energy Procedia, 16: 1874-1885.

Husnawan, M; Masjuki, H H; Mahlia, T M I and Saifullah, M G (2009). Thermal analysis of cylinder head carbon deposits from single cylinder diesel engine fueled by palm oil-diesel fuel emulsions. Applied Energy, 86: 2107-2113.

Ilker, S; Tanzer, E; Ilker, O and Ozgur, S (2011). Biodiesel production from animal fat-palm oil blend and performance analysis of its effects on a single cylinder diesel engine. Energy Education Science and Technology Part A: Energy Science and Research, 28(1): 505-514.

Jayed, M H; Masjuki, H H; Kalam, M A; Mahlia, T M I; Husnawan, M and Liaquat, A M (2011). Prospects of dedicated biodiesel engine vehicles in Malaysia and Indonesia. Renewable and Sustainable Energy Reviews, 15(1): 220-235.

Jeffrey, M; Bergthorson, A N and Thomson, M J (2015). A review of the combustion and emissions properties of advanced transportation biofuels and their impact on existing and future engines. Renewable and Sustainable Energy Reviews, 42: 13931417.

Kaur, H; Vipasha, V; Kumar, T and Isha (2017). Biodiesel produced from waste cooking oil the best alternative for fossil fuels. A Review. Int. J. Medical Science and Innovative Research (IJMSIR), 2: 136-142.

Lapuerta, M; Villajos, M; Agudelo, J R and Boehman, A L (2011). Key properties and blending strategies of hydrotreated vegetable oil as biofuel for diesel engines. Fuel Processing Technology, 92(12): 2406-2411.

Lawlor, V and Olabi, A G (2015). Review of scientific research regarding $\mathrm{PPO}$, tallow and RVO as diesel engine fuel. Fuel, 145: 25-38.

Li, H; Biller, P; Hadavi, S A; Andrews, G E; Przybyla, $\mathrm{G}$ and Lea-Langton, A (2013). Assessing combustion and emission performance of direct use of SVO in 
a diesel engine by oxygen enrichment of intake air method. Biomass and Bioenergy, 51: 43-52.

Lim, S and Teong, L (2010). Recent trends, opportunities and challenges of biodiesel in Malaysia: An overview. Renewable and Sustainable Energy Reviews, 14: 938-954.

Lim, S and Lee, K (2012). Implementation of biofuels in Malaysian transportation sector towards sustainable development: A case study of international cooperation between Malaysia and Japan. Renewable and Sustainable Energy Reviews, 16: 1790-1800.

Malaysian Standard (1993). Diesel Fuel-Specification, MS123:1993.

Marie, S; Branislav, S; Petr, V and Ivana, H (2020), FTIR spectrometry with PLS regression for rapid TBN determination of worn mineral engine oils. Energies, 13: 6438.

Masjuki, H H and Kalam, M A (2013). An overview of biofuel as a renewable energy source: Development and challenges. Procedia Engineering, 56: 39-53.

Masjuki, H H; Kalam, M A; Mofijur, $\mathrm{M}$ and Shahabuddin, M (2013). Biofuel: Policy, standardization and recommendation for sustainable future energy supply. Energy Procedia, 42: 577-586.

McCarthy, P; Rasul, M G and Moazzem, S (2011). Comparison of the performance and emissions of different biodiesel blends against petroleum diesel. Int. J. Low-Carbon Technologies, 6: 255-260.

Mittelbach, M and Remschmidt, C (2007). Biodiesel: The comprehensive handbook. Biotechnology J., 1(1): 102. DOI:10.102/ biot.200690003

Mofijur, M; Masjuki, H H; Kalam, M A; Ashrafur Rahman, S M and Mahmudul, H M (2015). Energy scenario and biofuel policies and targets in ASEAN countries. Renewable and Sustainable Energy Reviews, 46: 51-61.

Nagy, A L; Knaup, J and Zsoldos, I (2019). Investigation of used engine oil lubricating performance through oil analysis and friction and wear measurements. Acta Technica Jaurinensis, 12(3): 237-251.

Newell, G E (1999). Oil analysis cost-effective machine condition monitoring technique. Ind. Lubr. Tribol., 51: 119-124. DOI:10.1108 / 00368799910268066 Parveez, G K A; Elina, H; Soh, K H; Meilina, O B; Kamalrudin, M S; Mohd, N I Z B S; Shamala, S; Zafarizal, A Z H and Zainab, I (2020). Oil palm economic performance in Malaysia and $R \& D$ progress in 2019. J. Oil Palm Res., 32(2): 159-190.

Pelkmans, L and Debal, P (2006). Comparison of onroad emissions with emissions measured on chassis dynamometer test cycles. Transportation Research Part D, 11: 233-241.

Puppan, D (2002). Environmental evaluation of biofuels. Period Polytech. Ser. Soc. Man. Sci., 10: 95116.

Radhakrishnan, S; Devarajan, Y; Mahalingam, A and Nagappan, B (2017). Emissions analysis on diesel engine fueled with palm oil biodiesel and pentanol blends. J. Oil Palm Res., 29(3): 380-386.

Saiful Islam, M; Ahmed, A S; Islam, A; Abdul Aziz, S; Xian, L C and Mridha, M (2014). Study on emission and performance of diesel engine using Castor biodiesel. J. Chemistry, 2014: 8. DOI:10.115/2014/451526

Sendilvelan, S and Anandanatarajan, R (2017). Controlling silicon and soot content in the crank case oil to improve performance of diesel engine. J. Chemical and Pharmaceutical Sciences, 10(1): 185-188.

Shereena, K M and Thangaraj, T (2009). Biodiesel: An alternative fuel produced from vegetable oils by transesterification. Electronic J. Biology, 5(3): 6774.

Subhash, V L and Kizhaeral, S (2015). Effect of different percentages of biodiesel-diesel blends on injection, spray, combustion, performance and emission characteristics of a diesel engine. Fuel, 139: 537-545.

Uy, D; Zdrodowski, R J; O'neill, A E; Simko, S J; Gangopadhyay, A K; Morcos, M; Lauterwasser, F and Parsons, G (2011). Comparison of the effects of biodiesel and mineral diesel fuel dilution on aged engine oil properties. Tribol. Trans., 54: 749-763.

Valente, O S; Pasa, V M D; Belchior, C R P and Sodré, J R (2011). Physical-chemical properties of waste cooking oil biodiesel and castor oil biodiesel blends. Fuel, 90: 1700-1702.

Vališs, D; Libor, Z and Ondřej, P (2014). Failure prediction of diesel engine based on occurrence of selected wear particles in oil. Engineering Failure Analysis, 56: 501-511.

Varuvel, E G; Mrad, N; Tazerout, M and Aloui, F (2012). Experimental analysis of biofuel as an alternative fuel for diesel engines. Applied Energy, 94: 224-231. 
Wakiru, J; Pintelon, L; Chemweno, P and Muchiri, P (2017). Analysis of lubrication oil contamination by fuel dilution with application of cluster analysis. XVII International Scientific Conference on Industrial Systems. 4-6 October 2017. Novi Sad, Serbia.

Williamson, A M and Badr, O (1998). Assessing the viability of using rape methyl ester (RME) as an alternative to mineral diesel fuel for powering road vehicles in the United Kingdom. Applied Energy, 59(2-3): 187-214.

Xin, H; Aaron, W; Earl, C; Jonathan, B and Robert, M (2011). Biodiesel impact on engine lubricant dilution during active regeneration of aftertreatment systems. SAE International Journal Fuels Lubricants, 4: 158-178.

Yunus, S; Amirul, A R; Syazuan, A L; Nik Rosli A; Mohammad Ali, A and Abdul Hakim, A (2013). Comparative study of used and unused engine oil (Perodua Genuine and Castrol Magnatec Oil) based on property analysis basis. Procedia Engineering, 68: 326-330.

Zulqarnain; Mohd Hizami, M Y; Muhammad, A; Norwahyu, J and Ahmad Zuhairi, A (2020). The challenges of a biodiesel implementation program in Malaysia. Proceses, 8: 1244. 